\title{
Proposal Creating Incentive Programs to Motivate Employees in the Railway Repair Company
}

\author{
Miloš Hitka ${ }^{10000-0002-6567-7333]}$, Lenka Ližbetinová2[0000-0001-8969-2071], Silvia Lorin- \\ cová $^{[0000-0002-5763-5002]}$ and Bronislava Kopecká ${ }^{1}$ \\ ${ }^{1}$ Faculty of Wood Sciences and Technology, Technical University in Zvolen, T. G. Masaryka \\ 24, 96053 Zvolen, Slovakia; hitka@tuzvo.sk, silvia.lorincova@tuzvo.sk \\ ${ }^{2}$ Faculty of Corporate Strategy, The Institute of Technology and Business in Ceske \\ Budejovice, Czech Republic; lizbetinova@mail.vstecb.cz, kopecká@mail.vstecb.cz
}

\begin{abstract}
The aim of the paper is to propose the creation of incentive programs for employees in a railway repair company using cluster analysis. Using the Ward method, the Euclidean distance, we defined four groups of similarly motivationally oriented employees. The result of the analysis is a proposal for the creation of a group-individual motivational program, the content of which are common motivational factors for individual groups, which is specified by priority motivational factors for individual groups of employees. There are fundamental differences between different groups of employees.
\end{abstract}

Keywords: Motivational Program, Employee Motivation, Railway Transport Company.

\section{Introduction}

Employees are a source of high quality and competitive advantage [1]-[4], and therefore it is necessary not only to acquire them, but above all to maintain them [5], [6]. In order for a company to retain qualified employees, it must anticipate, identify and meet their current and future needs [7], [8], because only a motivated and satisfied employee can make a significant contribution to the success and competitiveness of the company [9], [10]. Keeping employees motivated and satisfied is more complicated, so managers should know their subordinates and know what each individual is responding to. Subsequently, they should be able to create an effective motivation system with the most appropriate motivational means and methods of motivation.

Human resources are linked to all other resources of the company. Their management is thus the most important part of the overall management of the organization [11], [12]. The area of strategic importance belongs to the basic competencies, capabilities or abilities of the company[13]. Human resource management can be defined as organizing the process of changes [14]-[16] in the structure and quality of human resources in accordance with the needs of the social and economic environment, the internal development goals of the organization and the requirements of employees. 
Part of human resource management is also the area of motivation and the creation of motivational programs, whether collective or for individuals [17]. Creating a costeffective incentive program is one of the key tasks of any business [18], [19]. The question is how to prepare an effective incentive program with which employees will be satisfied.

Employee satisfaction depends on many factors and their interactions. In business practice, it is necessary to obtain information about the opinions of employees on the importance of motivation factors and at the same time the degree of their job satisfaction with their implementation [20]. The attitude of employees is not constant and may change over time. Therefore, it is necessary to update the incentive program and adapt it to the value orientation of employees. The incentive program is understood as a comprehensive set of measures in the field of human resources management, which builds on other management activities of senior employees, aims to actively influence work performance and create positive attitudes to the organization of all its employees [21][23]. In this regard, it is mainly about strengthening the identification of the employee's interest with the employer's interests (loyalty to their own organization) [24] and the formation of the employee's interests in the development of their own knowledge, skills and abilities and their active use in the work process. These programs are also linked to employee training and development programs and systems and performance-based remuneration systems (salary + financial and non-financial remuneration as a motivating factor).

The aim of the paper is to create a proposal for an incentive program for similarly motivationally oriented employees was carried out in the railway repair company.

\section{Methodology}

The aim of the paper is to propose the creation of incentive programs for employees in a railway repair company using cluster analysis. Identifying the types of motivation of employees to customize business processes of a particular type of motivation, and thus create a differentiated incentive programs specifically targeted to individual groups of employees with similar motivation profiles. We present the proposed approach at a Slovak railway repair company. This also presents its applicability in practice. The analysis was attended by 45 workers, aged 45 to 60 years. To determine the level of motivation and to analyze the motivational factors of the company in the current time, we used a questionnaire consisting of 30 closed questions [25], which can be used to find information: on the characteristics of the working environment, working conditions, applied evaluation and remuneration system. the company, about the personnel work in the company itself, about the system of social care and employee benefits, as well as information about the satisfaction or dissatisfaction of the employee, his value orientation, relationship to work, colleagues and the company as a whole. In order not to influence the respondents, the motivational factors are arranged alphabetically. Employees could assign one of the five levels of importance from the Likert scale to each question. Questionnaires were evaluated using the STATISTICA 12 program. Questionnaires were evaluated using the STATISTICA 12 program. Descriptive statistics 
were used to characterize the sample. Subsequently, similar motivationally oriented groups were identified using cluster analysis, Ward's method, Euclidean distance. The goal is to achieve a state where the objects inside the clusters are as similar as possible and the objects from different clusters are as similar as possible. In the next part, there are the determined the profile of the created clusters and their characteristic properties.

\section{Results}

Table 1. Descriptive statistics of the motivational factors.

\begin{tabular}{|c|c|c|c|c|c|c|}
\hline & Min. & 1. Max. & Mean & $\begin{array}{c}\text { Std. } \\
\text { Error } \\
\end{array}$ & $\begin{array}{c}\text { Std. } \\
\text { Deviation } \\
\end{array}$ & Variance \\
\hline Atmosphere in the workplace & 4 & 5 & 4.82 & 0.058 & 0.387 & 0.149 \\
\hline Workplace safety & 4 & 5 & 4.69 & 0.070 & 0.468 & 0.219 \\
\hline Further financial evaluation & 1 & 5 & 4.44 & 0.129 & 0.867 & 0.753 \\
\hline Good working team & 2 & 5 & 4.07 & 0.140 & 0.939 & 0.882 \\
\hline Physical demands of work & 1 & 5 & 4.51 & 0.148 & 0.991 & 0.983 \\
\hline Job security & 3 & 5 & 4.44 & 0.087 & 0.586 & 0.343 \\
\hline Workplace communication & 2 & 5 & 4.13 & 0.133 & 0.894 & 0.800 \\
\hline Prestige of company name & 2 & 5 & 4.40 & 0.112 & 0.751 & 0.564 \\
\hline Possibility to use own abilities & 3 & 5 & 4.16 & 0.090 & 0.601 & 0.362 \\
\hline Content and type of work & 2 & 5 & 4.33 & 0.127 & 0.853 & 0.727 \\
\hline Feedback on work results & 3 & 5 & 4.53 & 0.093 & 0.625 & 0.391 \\
\hline Working time & 2 & 5 & 4.20 & 0.141 & 0.944 & 0.891 \\
\hline Work environment & 2 & 5 & 4.18 & 0.097 & 0.650 & 0.422 \\
\hline Carieer development & 1 & 5 & 4.04 & 0.152 & 1.021 & 1.043 \\
\hline Work performance & 1 & 5 & 3.89 & 0.143 & 0.959 & 0.919 \\
\hline Powers & 3 & 5 & 3.98 & 0.117 & 0.783 & 0.613 \\
\hline Prestige - work position & 2 & 5 & 4.42 & 0.117 & 0.783 & 0.613 \\
\hline Supervisor's approach & 3 & 5 & 4.33 & 0.095 & 0.640 & 0.409 \\
\hline Mental burden & 2 & 5 & 4.40 & 0.112 & 0.751 & 0.564 \\
\hline Independent decision-making & 1 & 5 & 4.16 & 0.159 & 1.065 & 1.134 \\
\hline Self-realization & 1 & 5 & 4.42 & 0.160 & 1.076 & 1.159 \\
\hline Social benefits & 1 & 5 & 4.33 & 0.159 & 1.066 & 1.136 \\
\hline Fair evaluation of the employee & 1 & 5 & 4.07 & 0.157 & 1.053 & 1.109 \\
\hline Recognition (working) & 1 & 5 & 4.09 & 0.152 & 1.019 & 1.037 \\
\hline Company vision & 1 & 5 & 4.00 & 0.131 & 0.879 & 0.773 \\
\hline Free time & 1 & 5 & 4.18 & 0.150 & 1.007 & 1.013 \\
\hline Development of the region & 2 & 5 & 4.07 & 0.129 & 0.863 & 0.745 \\
\hline Education and personal growth & 1 & 5 & 3.84 & 0.162 & 1.086 & 1.180 \\
\hline Ecological company thinking & 1 & 5 & 4.27 & 0.150 & 1.009 & 1.018 \\
\hline Basic salary & 1 & 5 & 4.33 & 0.168 & 1.128 & 1.273 \\
\hline
\end{tabular}

Source: own research 
The incentive program for similarly motivationally oriented employees in the railway repair company was created in 2020 on a sample of 45 employees. Based on the evaluation of motivational factors of the required state of motivation obtained from questionnaire surveys, it is possible to define arithmetic averages of individual motivational factors in individual years (Table 1). The most important motivating factors of the company's employees include work procedure, atmosphere at the workplace, safety at the workplace, getting acquainted with the achieved work result, physical demands of the job, further financial evaluation, job security, prestige, self-realization and company name.

Subsequently, we defined similarly motivationally oriented groups of employees. Their selection was conditioned on the use of a data matrix $X$ of type $n \times p$, where $n$ was the number of objects, ie the number of evaluations by employees and $p$ is the number of variables, ie the evaluation criteria (Figure 1).

The first similarly motivationally oriented group of employees consists of employees 1, 2, 5, 29 and 30. The second similarly motivationally oriented group of staff consists of employees: $3,44,40,17,28,32,24,25,13,22$ and 23 . The third group consists of employees 4, 8, 21, 14, 19, 20, 39, 12, 45, 27, 6, 31, 36, 37, 38, 11, 42, 41 and 9. The last group consists of employees 7, 15, 16, 35, 43, 18, 33, 34 and 26.

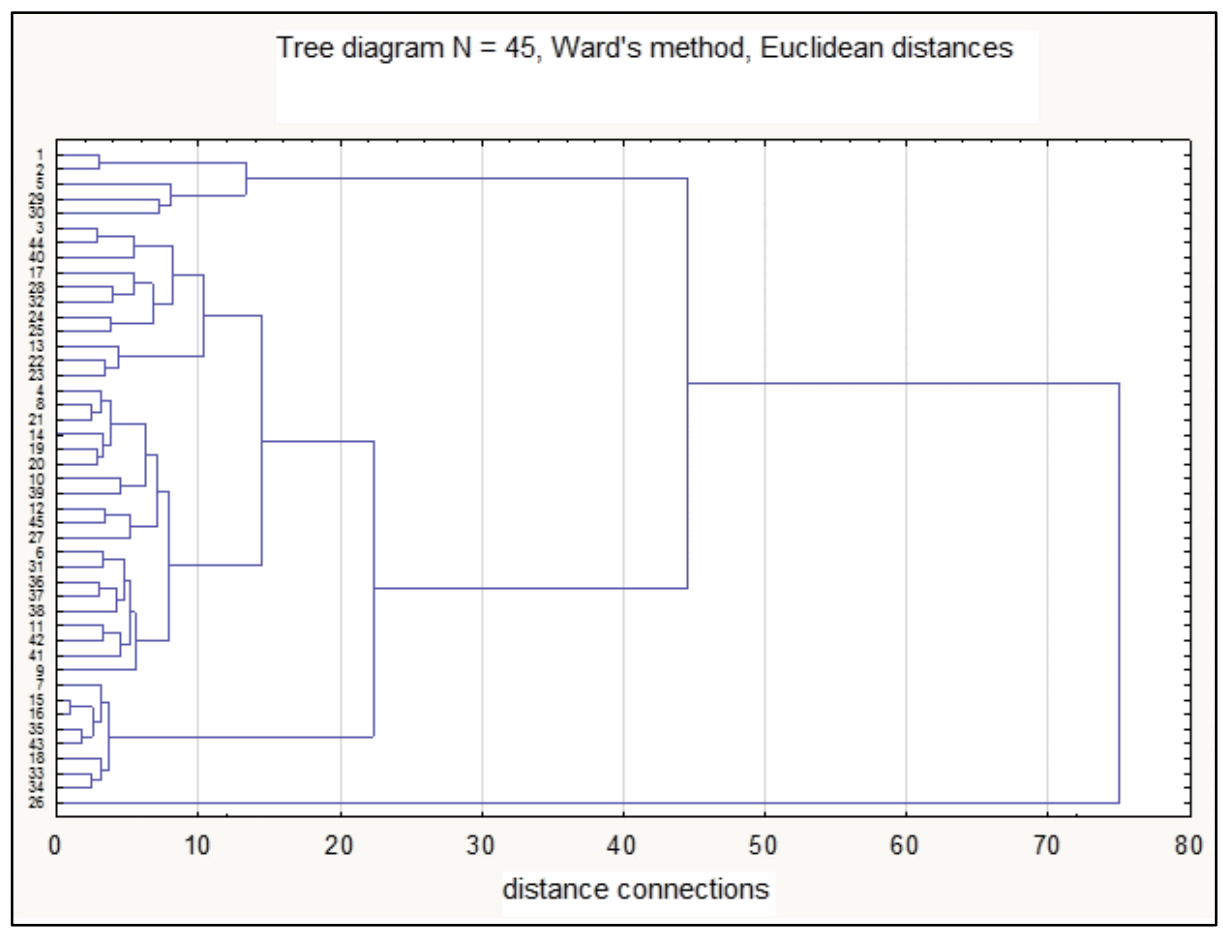

Fig. 1. Defining similarly motivationally oriented groups; Source (own research). 
Table 2. The order of importance of incentives for employee's groups.

\begin{tabular}{lc}
\hline Group 1 & \\
\hline Atmosphere in the workplace & 5.00 \\
Workplace safety & 4.80 \\
Job security & 4.80 \\
Feedback on work results & 4.80 \\
Possibility to use skills & 4.20 \\
Group 2 & \\
\hline Physical demands of work & 4.82 \\
Atmosphere in the workplace & 4.73 \\
Workplace safety & 4.64 \\
Basic salary & 4.55 \\
Further financial evaluation & 4.45 \\
Group 3 & \\
\hline Physical demands of work & 4.85 \\
Atmosphere in the workplace & 4.80 \\
Self-realization & 4.80 \\
Further financial evaluation & 4.75 \\
Social benefits & 4.70 \\
Group 4 & \\
\hline Prestige & 5.00 \\
Self-realization & 5.00 \\
Social benefits & 5.00 \\
Fair evaluation of the employee & 5.00 \\
Recognition (working) & 5.00 \\
\hline Source: own research & \\
\hline
\end{tabular}

Source: own research

With regard to the results of the analysis, we propose for the company the creation of a motivational program of the company group-individual motivational program, the content of which are motivational factors for individual groups of employees.

\section{Conclusion}

Human resources are the most important factor determining a company's performance. It is therefore necessary to pay due attention to them. Employees can have the skills, the best technology, but they do not have to provide the required performance, if they do not have the desire and the will to work. Therefore, an equally important element of employee performance is motivation. It is the motivation that should ensure that employees will want to work and produce the best possible performance. The reason will not be the demands placed on their performance, but their need to satisfy their needs. Surveys of the motivational needs of employees accept the general knowledge of the theory of work motivation and are one of the first gradual steps in creating a motivational program of the company. Together with the methods of psychological and 
sociological surveys, they make it possible to evaluate the initial state in the company in the field of human resources. They also define the weaknesses and strengths of the management system and its motivational effects.

The comparison of average evaluations of motivational factors enables a general analysis of the motivational structure and its changes within the category of workers and is sufficient to develop a unified, unified motivational program. The possibility of distinguishing groups of similarly motivationally oriented employees was explored by means of cluster analysis, in order to better adapt motivational programs to specific people and subsequently increase their effectiveness. In particular, this issue is highly topical in larger companies with a higher number of employees, because a unified incentive program created by averaging a larger number of individual opinions may be relatively far from the needs of specific people, especially with greater variability of individual motivational profiles. Thus, this program may be ineffective for a large part of the target group of employees. On the contrary, the development of fully individual incentive programs (often for hundreds of employees) is practically unmanageable and, given the existence of groups of employees with a similar incentive profile, also unjustified.

The grouping should help us answer the questions: Are there certain motivational types in the company (ie groups of people with similar motivational profiles)? How many such types are there? What is the characteristic of a particular type and how do they differ significantly from each other? Based on the created clusters, we can then use the similarity of respondents' motivational opinions when including motivators in motivational programs.

In the analyzed group, with the help of cluster analysis we were able to distinguish four basic groups of similarly motivationally oriented employees. Creating a higher number of groups has proved ineffective, the differences in motivational profiles are only small and therefore difficult to interpret. However, with a larger number of employees, we do not rule this out in the future.

If a person accepts work as an integral part of his life and the achievements at work are an important criterion for him of his own self-evaluation, then we would state that the person has identified with the work. The employee identifies with the company, understands the goals of the company as their own and so there is no conflict between personal and corporate goals. If the employee's identification with the work is linked to the employee's identification with the company's goals, the employee's work performance is high in the long run, he works economically, he is creative, responsible and active. The employee's work is most effective in this case. Especially the work of an employee who is in direct contact with the customer is important and requires great motivational attention from management. Motivation integrates a person's mental and physical activity towards a set goal, and is thus tied to a person's internal needs.

We must take into account the external and internal environment of the company when considering the economic evaluation of the introduction of the analysis of motivational factors used in the incentive program. In the analysis of the external environment, we take into account the changes taking place in politics, legislation, economics, technology, technology, the environment, demographic development, socio-cultural areas, etc [2], [26]-[28]. When analyzing the internal environment of the company, we 
take into account the factor of the situation, including the analysis of the company's chances on the market in terms of quality and character [29]-[31]. This includes the company's internal resources, economic, environmental and social problems of the company, image, performance potential, goals, etc. The external environment must be respected, because the company cannot influence it directly[32]-[40]. The internal environment [31], [41] can be modified to some extent by the company's management. A proven method for analysis, which can be used to evaluate the characteristics of the external and internal environment is SWOT analysis, ie analysis of the strengths and weaknesses of the company.

\section{Acknowledgements}

This research was supported by projects: SVV202002 Trends in human resource management in transport and logistics companies, APVV-17-0656titled Transformation of Paradigm in Management of Organizations in the Context of Industry 4.0, TL02000017 Inter-generation cooperation in digitalization, TL02000559 Safe cities for pedestrians and seniors and TL01000349 Stabilization and development of SMEs in rural areas, KEGA 005TU Z-4/2020 Economics, Management and Enterprising in Wood Industry Companies - university textbook with visualization support in virtual space and the Operational Programme Integrated Infrastructure (OPII) funded by the ERDF: Progressive research of performance properties of wood-based materials and products (LignoPro).

\section{References}

[1] E. Loučanová, M. Olšiaková, and M. Dzian, "Suitability of innovative marketing communication forms in the furniture industry," Acta Fac. Xylologiae, vol. 60, no. 1, pp. $159-171,2018$

[2] J. Chocholac, D. Sommerauerova, J. Hyrslova, T. Kucera, R. Hruska, and and S. Machalik, "Service quality of the urban public transport companies and sustainable city logistics," Open Eng., vol. 10, no. 1, pp. 86-97, 2020.

[3] L. Vilčeková and P. Štarchoň, CONSUMER PERCEPTION OF SELECTED BRANDS EXPLORED THROUGH ARCHETYPES. 2017.

[4] E. Smolková and P. Štarchoň, "Specifics of Marketing Communications Within Political Environment in Slovakia," Springer, Cham, 2019, pp. 39-51.

[5] L. Kohnová and N. Salajová, "Industrial Revolutions and their impact on managerial practice: Learning from the past," Probl. Perspect. Manag., vol. 17, no. 2, pp. 462-478, Jun. 2019.

[6] J. Papula, L. Kohnová, Z. Papulová, and M. Suchoba, "Industry 4.0: Preparation of Slovak Companies, the Comparative Study,” 2019, pp. 103-114.

[7] L. Kohnová, J. Papula, and Z. Papulová, "Cooperation Models for Employee Education: Analysis on Slovak and Czech Companies,” Springer, Cham, 2020, pp. 307-319.

[8] M. Sedliačiková, Z. Stroková, J. Drábek, and D. Malá, "Controlling implementation: What are the benefits and barries for employees of wood processing enterprises?," Acta 
Fac. Xylologiae Zvolen, vol. 61, no. 2, pp. 163-173, 2019.

[9] A. Kucharčíková and M. Mičiak, "Human capital management in transport enterprises with the acceptance of sustainable development in the Slovak Republic," Sustain., vol. 10, no. 7, 2018.

[10] M. Sedliačiková, Z. Stroková, J. Klementová, A. Šatanová, and M. Moresová, “Impacts of behavioral aspects on financial decision-making of owners of woodworking and furniture manufacturing and trading enterprises," Acta Fac. Xylologiae Zvolen, vol. 62, no. 1 , pp. 165-176, 2020.

[11] E. Tokarčíková, A. Kucharčíková, and M. Ďurišová, "Corporate social responsibility managers and their decision making," Turkish Online J. Educ. Technol., vol. 2017, no. October Sp, pp. 654-664, 2017.

[12] T. Nosková, M., Peráček, "TERMINATION OF EMPLOYMENT IN THE SLOVAK REPUBLIC AS A KEY ISSUE OF HR MANAGEMENT," Cent. Eur. J. Labour Law Pers. Manag., vol. 2, no. 2, pp. 44-59, Dec. 2019.

[13] Z. Joniaková and J. Blštáková, “Age Management as Contemporary Challenge to Human Resources Management in Slovak Companies," Procedia Econ. Financ., vol. 34, pp. 202-209, Jan. 2015.

[14] N. Jankelova, Z. Joniakova, J. Blstakova, and I. Nemethova, "Readiness of human resource departments of agricultural enterprises for implementation of the new roles of human resource professionals," Agric. Econ. (Czech Republic), vol. 63, no. 10, pp. 461470, Oct. 2017.

[15] K. Mészáros, M., Divékyová, "IMMEDIATE TERMINATION OF EMPLOYMENT RELATIONSHIP BY THE EMPLOYER," Cent. Eur. J. Labour Law Pers. Manag., vol. 2, no. 2, pp. 33-43, Dec. 2019.

[16] L. Mura and D. Vlacseková, "Motivation of public employees: Case study of slovak teaching and professional staff," Adm. si Manag. Public, vol. 2018, no. 31, pp. 67-80, 2018.

[17] K. Stachová, Z. Stacho, J. Blštáková, M. Hlatká, and L. M. Kapustina, "Motivation of employees for creativity as a form of support to manage innovation processes in transportation-logistics companies," Nase More, vol. 65, no. 4 Special issue, pp. 180186, 2018.

[18] A. Kucharčíková and M. Mičiak, "Human capital management in transport enterprise," in MATEC Web of Conferences, 2017, vol. 134, p. 00030.

[19] J. Papula and J. Volná, "A Descriptive Analysis of Intellectual Capital Concept Implementation Within Slovak Companies," in Driving the Economy through Innovation and Entrepreneurship, Springer India, 2013, pp. 443-451.

[20] Z. Stacho, K. Stachová, J. Papula, Z. Papulová, and L. Kohnová, "Effective communication in organisations increases their competitiveness," Polish J. Manag. Stud., vol. 19, no. 1, pp. 391-403, Jun. 2019.

[21] L. Mura and D. Vlacseková, "Motivation of public employees: Case study of slovak teaching and professional staff," Adm. si Manag. Public, vol. 2018, no. 31, pp. 67-80, 2018.

[22] Z. Caha, "Central Europe: Ethical Overlaps of Environmental and Economic Interests in Coming Years," Sci. Eng. Ethics, vol. 24, no. 6, pp. 1801-1807, Dec. 2018.

[23] M. Seilerová, “THE CONSEQUENCES OF PSYCHOSOCIAL RISKS IN THE 
WORKPLACE IN LEGAL CONTEXT,” Cent. Eur. J. Labour Law Pers. Manag., vol. 2, no. 1, pp. 47-60, Sep. 2019.

[24] L. Mura, B. Gontkovicova, E. D. Spisakova, and Z. Hajduova, "Position of employee benefits in remuneration structure," Transform. Bus. Econ., 2019.

[25] M. Hitka and M. Sirotiaková, "MOTIVATIONAL GROWTH OF EMPLOYEES' PERFORMANCE," Ekonomika, 2009.

[26] P. Lejsková, L. Dvořák, D. Gottwald, "Knowledge Managemet Models in Creating, Sharing, Using and Managing the Knowledge and Iinformation of a Company" nternational Scientific Conference on Knowledge for Market Use - People in Economics - Decisions, Behavior and Normative Models, Olomouc, SEP 07-08, 2017, 883-889.

[27] D. Gottwald; P. Lejskova; L. Svadlenka; V. Rychnovska, Evaluation and Management of Intellectual Capital at Pardubice Airport: Case Study. 9th International Scientific Conference on Business Economics and Management (BEM), Tech Univ Zvolen, Izmir, TURKEY, APR 30-MAY 02, 2015. vol. 34, 121-128.

[28] R. Hruška, T. Kučera, J. Hyršlová, S. Machalík, J. Chocholáč, and D. Sommerauerová, "Smart city concept of selected cities in the Czech Republic," in Transport Means Proceedings of the International Conference, 2019, vol. 2019-Octob, pp. 279-284.

[29] Z. Riha, V. Nemec, and R. Sousek, "Transportation and environment-economic research," in WMSCI 2014 - 18th World Multi-Conference on Systemics, Cybernetics and Informatics, Proceedings, 2014, vol. 2, pp. 212-217.

[30] M. Dobrodolac, D. Lazarević, L. Švadlenka, and M. Živanović, "A study on the competitive strategy of the universal postal service provider," Technol. Anal. Strateg. Manag., 2016.

[31] J. Motykova and L. Svadlenka, "STATISTICAL ANALYSIS AND FORECASTING OF RAIL TRANSPORT ACCIDENTS IN THE CZECH REPUBLIC," in SGEM 2016, BK 2: POLITICAL SCIENCES, LAW, FINANCE, ECONOMICS AND TOURISM CONFERENCE PROCEEDINGS, VOL V, 2016.

[32] R. Kampf, O. Stopka, I. Kubasakova, and V. Zitricky, "Macroeconomic Evaluation of Projects Regarding the Traffic Constructions and Equipment," in Procedia Engineering, 2016, vol. 161, pp. 1538-1544.

[33] O. Stopka, L. Bartuška, and R. Kampf, "Integrirani prijevozni sustavi - Procjena putnika," Nase More, vol. 62, no. 3, pp. 153-157, 2015.

[34] V. Zitrický, L. Černá, and B. Abramovič, "The Proposal for the Allocation of Capacity for International Railway Transport," in Procedia Engineering, 2017, vol. 192, pp. 994999.

[35] J. Ližbetin, "Methodology for Determining the Location of Intermodal Transport Terminals for the Development of Sustainable Transport Systems: A Case Study from Slovakia,” Sustainability, vol. 11, no. 5, p. 1230, Feb. 2019.

[36] L. Bartuška, L. Černá, and J. Daniš, "Usporedbe troškova i mogućnosti povećanja prijevoznih kapaciteta selekcijom prikladnih željezničkih vagona," Nase More, vol. 63, no. 3, pp. 93-97, 2016.

[37] E. Nedeliakova, M. Panak, J. Ponicki, and R. Sousek, "Progressive Management Tools for Quality Improvement," 2016, pp. 195-198.

[38] E. Nedeliaková, V. Stefancová, and A. Kuka, "Innovative Methodology For Quality And Risk Management In Logistics Processes Of Transport Undertakings,” Bus. Logist. 
Mod. Manag., vol. 18, pp. 41-53, 2018.

[39] R. Kampf, M. Hlatká, and L. Bartuska, "Optimization of Production Logistics," Adv. Sci. Technol. Res. J., vol. 12, no. 4, pp. 151-156, Dec. 2018.

[40] V. Nyvlt, "The role of managing knowledge and information in BIM implementation processes in the Czech Republic". Conference: 9th International Scientific Conference on Building Defects (Building Defects), Inst Technol \& Business, Ceske Budejovice, CZECH REPUBLIC, NOV 23-24, 2017, MATEC Web of Conferences, vol. 146, Article Number: 01003

[41] R. Kampf, P. Průša, and C. Savage, "Systematic location of the public logistic centres in Czech Republic,” Transport. 2011. 